\title{
Possibility for Heliotropism from Inclined Columns of Stromatolites, Socheong Island, Korea
}

\author{
Dal-Yong Kong ${ }^{1}$ and Seong-Joo Lee ${ }^{2, *}$ \\ 'National Research Institute of Cultural Heritage, Daejeon 302-834, Korea \\ ${ }^{2}$ Department of Geology, Kyungpook National University, Daegu 702-701, Korea
}

\begin{abstract}
Socheong island is a unique island containing Precambrian stromatolites in South Korea. Most of Socheong stromatolites are domes and columns, occurring as $10 \mathrm{~cm}$ to $1 \mathrm{~m}$ thick stromatolite beds. Lower parts of the stromatolite beds are predominantly composed of domes, but columns increase toward the upper level of stromatolite beds. In many of the stromatolite beds, inclined columns are easily identifiable, which is generally considered as a result of heliotropism. From general lithology, sedimentary structures, inclined angles and distributional pattern, and structural deformation of sedimentary rocks of Socheong island, the inclination of Socheong stromatolites could be better interpreted as a secondary structural deformation probably after formation of stromatolite columns, rather than as a result of heliotropism. However, at this moment, we do not clearly reject heliotropism interpretation for inclined columns of Socheong stromatolites. This is because the original position of stromatolite columns could have been lost if structural deformation had affected the whole sedimentary rocks of Socheong island.
\end{abstract}

Keywords: heliotropism, inclined columns, Precambrian, Socheong island, columnar stromatolites

\section{Introduction}

Many organisms tend to move toward the direction of sunlight in response to the stimulus of light because the sunlight is a fundamental energy source for life. This phenomenon, called as "heliotropism", is particularly and easily identifiable in photosynthetic organisms including plant, aquatic algae and even bacteria (Golubic and Focke, 1978; Kudo, 1995; Whippo, 2006). The term "heliotropism" refers to positive movement of a whole organism or part of an organism toward the direction of increasing intensity of sunlight. Such a positive movement of organisms often produces interesting directional structures in sedimentary rocks, particularly in stromatolite.

Heliotropism was clearly documented from modern

\footnotetext{
*Corresponding author: sjl@knu.ac.kr

Tel: +82-53-950-5355

Fax: $+82-53-950-5362$
}

This is an Open-Access article distributed under the terms of the Creative Commons Attribution Non-Commercial License (http:// creativecommons.org/licenses/by-nc/3.0) which permits unrestricted non-commercial use, distribution, and reproduction in any medium, provided the original work is properly cited. stromatolites of Hamelin Pool of Shark Bay, Australia (Awramik and Vanyo, 1986), and from Yellowstone National Park, USA (Vanyo et al., 1986), all of which are built predominantly by photosynthetic cyanobacteria. In both cases, filamentous cyanobacteia forming microbial mats on the sediment surface orient to the direction of incident sunlight, finally constructing inclined stromatolite tuffs. Such a heliotropism was also detected from Precambrian stromatolites (Anabaria juvensis, from the Bitter Springs Formation of the Amadeus Basin, central Australia; Vanyo and Awramik, 1982, 1985 fig.3). They reported both inclination and sinusoidal growth pattern of stromatolite columns from the Bitter Springs Formation. Based on such observations, they insisted that heliotropism would have produced the inclination of the Precambrian stromatolite columns, non-vertical direction against water-sediment interface due to a positive movement toward solar radiation. This is mainly because photosynthetic cyanobacteria are main builder of stromatolites (Golubic, 1976; Golubic et al., 2000; Seong-Joo et al., 2000).

The Socheong Island contains less-metamorphosed Precambrian sedimentary sequences where closely spaced stromatolite domes and columns form a 
characteristic stromatolitic reef (Kim and Kim, 1999; Lee et al., 2003). Inclined columns of stromatolites were found within such stromatolite beds, which may reflect heliotropism at time of deposition of Socheong stromatolites. Here we present our findings of inclined columns of Korean stromatolites, and discuss the validity of heliotropism and sinusoidal growth model of Precambrian columnar stromatolites.

\section{Geological settings and stratigraphic correlation}

Socheong island is a small island located in Daecheong-myeon, Ongjin-gun, Incheon, and is close to southern part of the Pyeongnam Basin where the Sangweon System of North Korea is widely distributed (Pak, 1986; Paik et al., 1996). It is composed mainly of Precambrian low-grade metamorphic sedimentary rocks including clastic sediments, and grey limestone to pinkish marble containing stromatolites (Kim and Kim, 1999; Lee et al., 2003, Kim and Han, 2010; fig. 1). The strike and dip of the sedimentary rocks in Socheong island are, in average, $\mathrm{N} 59-69^{\circ} \mathrm{E}, 70^{\circ} \mathrm{SE}$, respectively. Diverse sedimentary structures such as cross-bedding, ripple marks and raindrop marks are easily observed on the bedding planes, indicating that the sediments were deposited in shallow marine environments (Kim and Kim, 1999; Kim et al., 1999; Kong, 2010).

Most limestones are slightly to highly metamorphosed due to intrusion of massive igneous rocks which are observed in the south - western part of the island (Fig. 2A). In a highly metamorphosed area (Fig. 1, Loc 1), stromatolitic carbonates were turned into white to pinkish marbles, causing loss of characteristic structures of stromatolites (e.g., fine lamination). In a less metamorphosed area (Fig. 1, Loc 2), on the contrary, stromatolites occur as small domes or columns with fine lamination. Domes and columns are attached together forming centimeter to meter scale stromatolite beds.

There have been a few studies on stratigraphy and geological age of Socheong island. Based on stromatolite morphotypes of the Socheong island, Kim and Kim (1999) suggested that Socheong island belongs to the Mokcheon and Myeolaksan Series of upper Sangweon System (Middle Neoproterozoic) of North Korea, and correlated Socheong sedimentary sequences with the Qingbaikou System of China. Such interpretation seems reasonable given that strikes and dips of sedimentary strata in Socheong island (i.e., strike and dip) are almost identical with those of Kirin and Changrin island in North Korea (Paek et al., 1996). Based on the comparison of stromatolites of those islands, Kim and Kim (1999) also came to similar conclusion on geological age of Socheong island. However, determination of depositional age of Socheong island based on stromatolite comparison needs to be cautious because gross morphology and internal structures of Socheong stromatolites were severely deformed, which causes, at least to a certain extent, ambiguity of stromatolite classification (Komar, 1964; Hofmann, 1976; Krylov, 1976; Petrov, 1996). Low diversity of Socheong stromatolites also hampers an accurate stratigraphic correlation (Walter et al., 1992).

Lee et al. (2003) reported some of poorly preserved bacterial microfossils such as Siphonophycus inornatum, S. robustum, Obruchevella sp., Sphaerophycus sp. from the Socheong stromatolites. Most of the bacterial microfossils discovered, however, are of little use for stratigraphic correlation and determination of geologic age of sedimentary rocks. This is partly due to the fact that most of Precambrian bacterial fossils have been reported in a wide range of periods, from the Archean to the Proterozoic (Knoll and Golubic, 1992; Schopf, 1996). In particular, a filamentous bacterial microfossil, Siphonophycus, and a coccoid bacterial microfossil, Sphaerophycus, have been discovered widely from the late Archean to the Neoproterozoic Era. Consequently, they could not be used as indicators of depositional age of the Socheong stromatolites (Lee et al., 2003).

On the other hand, Lee et al. (2003) suggested that Socheong stromatolites would have been deposited during the Late Neoproterozoic Era based on 


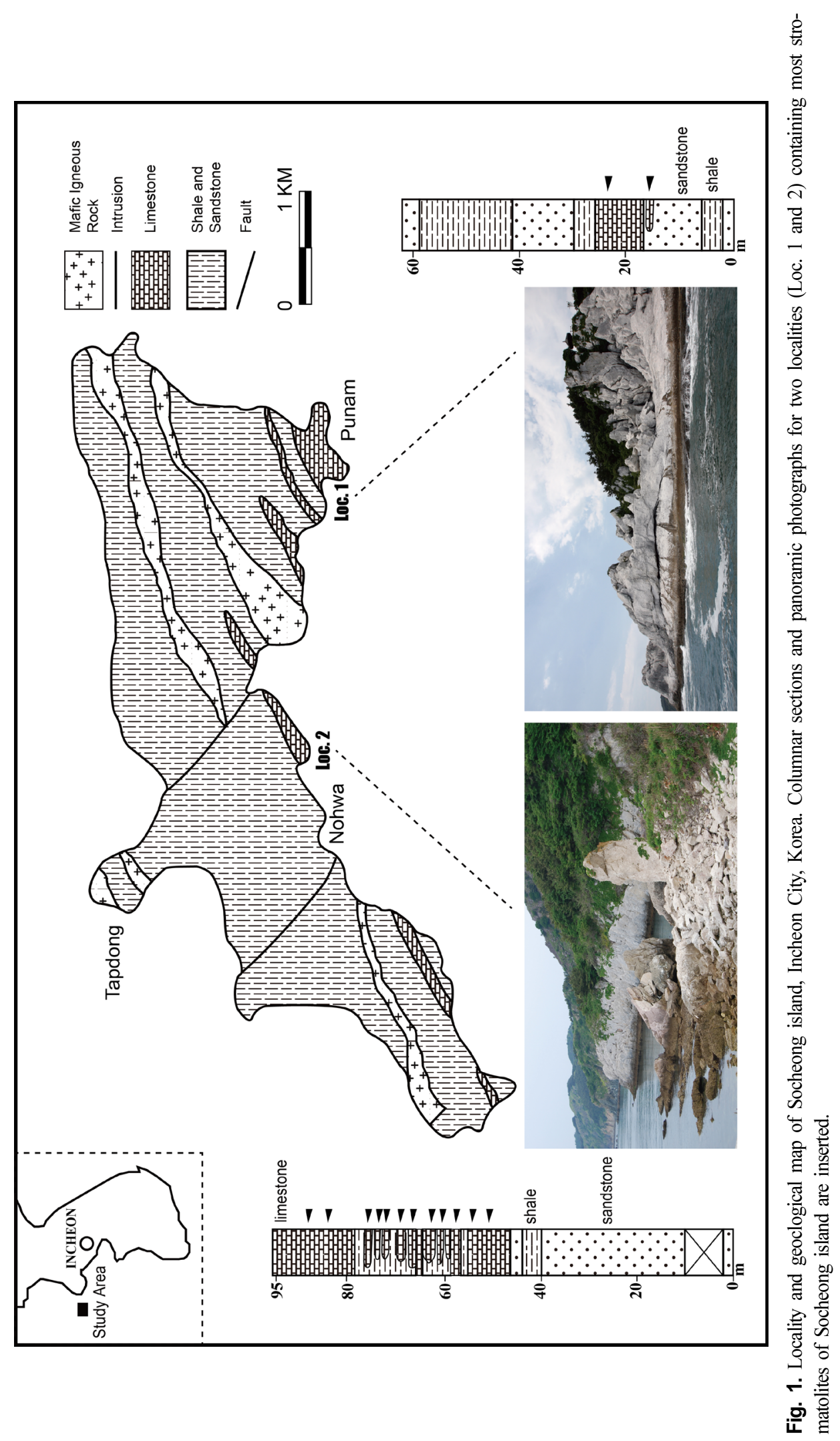


occurrence of four specimens of Obruchevella (coiled filamentous microfossil). Since its first discovery in 1948 by Reitlinger, 15 species of Obruchevella have been reported (Golovenok, 1989; Golovenok et al., 1989; Mankiewicz, 1992; Golovenok and Belova, 1994). Fossil Obruchevella has rarely been reported in the rocks older than the Neoproterozoic Era $(1,000$ Ma) and most of them have been found in the middle Neoproterozoic Era (Golovenok and Belova, 1994). It can be, therefore, concluded that sedimentary strata of Socheong island were deposited during the Neoproterozoic Era.

\section{Socheong Stromatolites}

Although about $40 \%$ of Korean peninsula is composed of Precambrian rocks and a great amount of the Precambrian stromatolites have been reported from North Korea, Socheong island is only one area where the Precambrian stromatolites are found in South Korea; recently, precambrian stromatolites have been detected by authors from Maldo of Gunsan City, but not clearly documented yet. In Socheong island, stromatolites are observed at seven localities, and stromatolite beds forming a reef structure are found only in two localities (Loc. 1 and Loc. 2 at Fig. 1). In Punam area (Loc. 1) where stromatolites are most dominantly found, carbonate beds were metamorphosed into white to pinkish marble due to intrusion of igneous rocks. Consequently, most stromatolites in Punam area were highly metamorphosed leaving a few characteristic features of stromatolites (Fig. 2C, D, E). On the other hand, relatively well-preserved Socheong stromatolites are found at Loc. 2 near Nohwa village where domal and columnar stromatolites are predominantly observed (Fig. 3). Stratiform stromatolites characterized by planar wavy lamination, in Loc. 2 of Fig. 1, are also found within reddish sandy beds (Lee et al., 2003).

The columns and/or domes of stromatolites are attached together forming up to 1 meter thick stromatolite beds (Fig. 3A, C). A few stromatolite beds are composed of a single stromatolite morphotype, columnar (Fig. 3B) or domal (Fig. 3D) stromatolite, while most beds consist of mixture of domal and columnar stromatolites. A columnar stromatolite shows simple non-branching morphology (ca. $3 \mathrm{~cm}$ wide and up to $20 \mathrm{~cm}$ high) and columns of stromatolites are tightly attached each other to form $10 \mathrm{~cm}$ to 1 meter thick stromatolite beds. In some stromatolite beds (Fig. 6A), domes are found only at lower part of the stromatolite beds and the number of columns increases in abundance toward upper part of the beds. This indicates that growth of Socheong stromatolite seems to have initiated as a small dome structure like an oncoid finally growing into a vertically erected column. Spaces between adjacent columns and between adjacent domes are filled with silt to sand sized clastic sediments.

Four stromatolite genera were identified from the Socheong island; Baicalia, Inzeria, Linella, and Jinshanzhaiella (Kim and Kim, 1999). However, both gross morphology and internal structure of Socheong stromatolites were not well documented in their study, due to metamorphism, and even fine laminations (diagnostic feature of stromatolites) are not clearly discernible both in the field and even thin sections (Fig 3D, E). It is, thus, hard to assign a scientific name of Socheong stromatolites because the shape and internal structures including fine lamination are severely destroyed (e.g., Semikhatov et al., 1979). Even the generic identification of Socheong stromatolites needs to be reconsidered although the nomenclatural problem is beyond the scope of this paper. More, well-preserved specimens and systematic approaches are needed for the accurate identification.

\section{Directional Structure of Socheong Stromatolites}

A complete assesment of stromatolite morphogenesis is a biological response to physico-chemical parameters under a certain depositional environment (Hofmann, 1969; Walter et al., 1976; Petrov, 1996), which yields various morphologic characters of stromatolites according to various combination of environmental and biological 

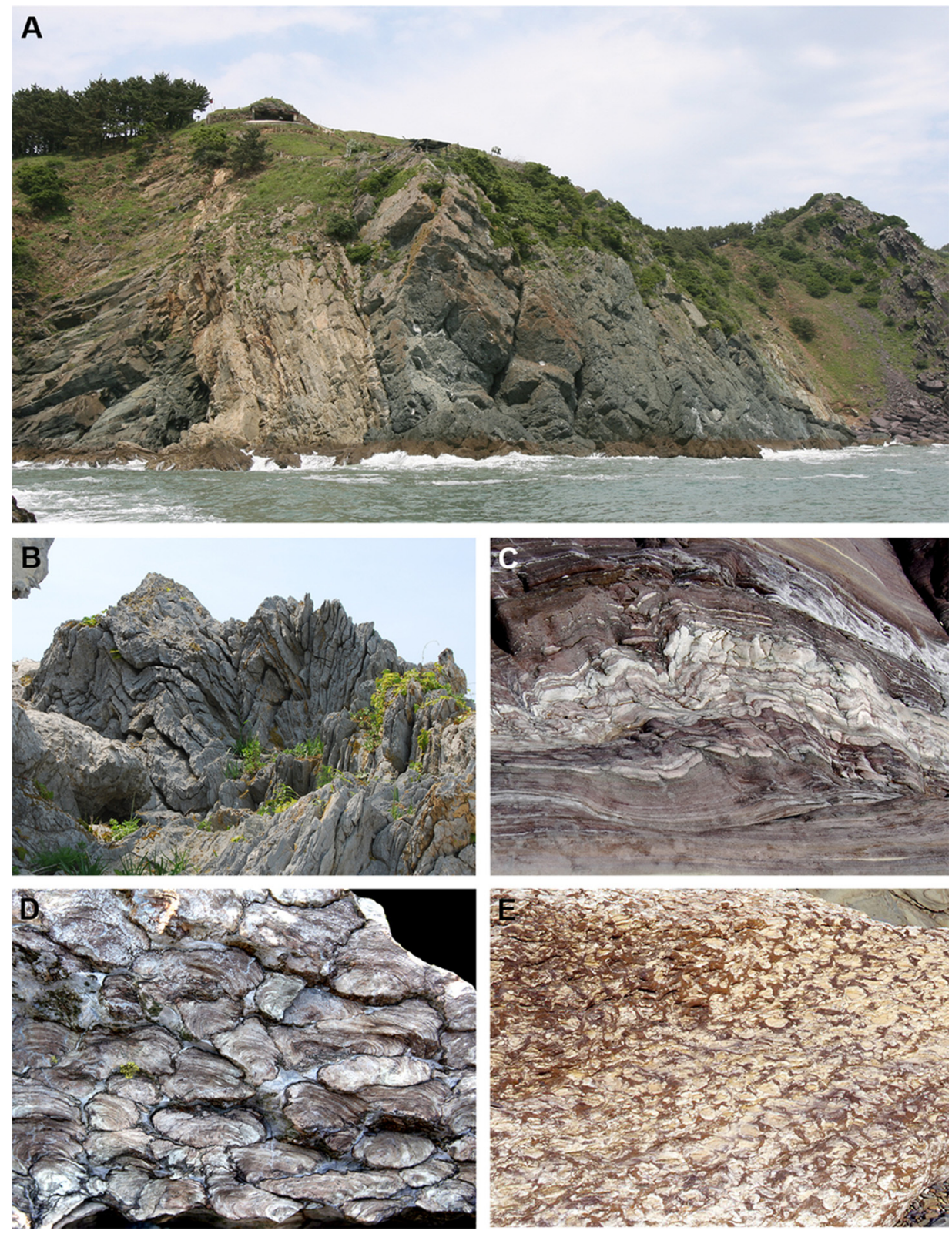

Fig. 2. Structural deformation caused by intrusion of igneous rocks. (a) mafic intrusive bodies between yellowish sandstone bodies. (b, c) macro- and micro folding structures. Stromatolites were severely deformed by intrusion, leading compaction (d) of stromatolite domes and (e) leaving no characteristic structures of stromatolites.

factors. In this context, three different types of directional structures are identified from the Precambrian stromatolites: i) fine lamination, ii) vertically erected columns and iii) linear structures on stromatolite surface (e.g., Seong-Joo et al., 2000). All three structures are also observed from the Socheong stromatolites.

The fine lamination, a diagnostic feature of stromatolites, represents alternating and stacking of sediment-rich and organic-rich layers. Organic-rich layers form when biologic factors play more important role in the course of stromatolite growth while 

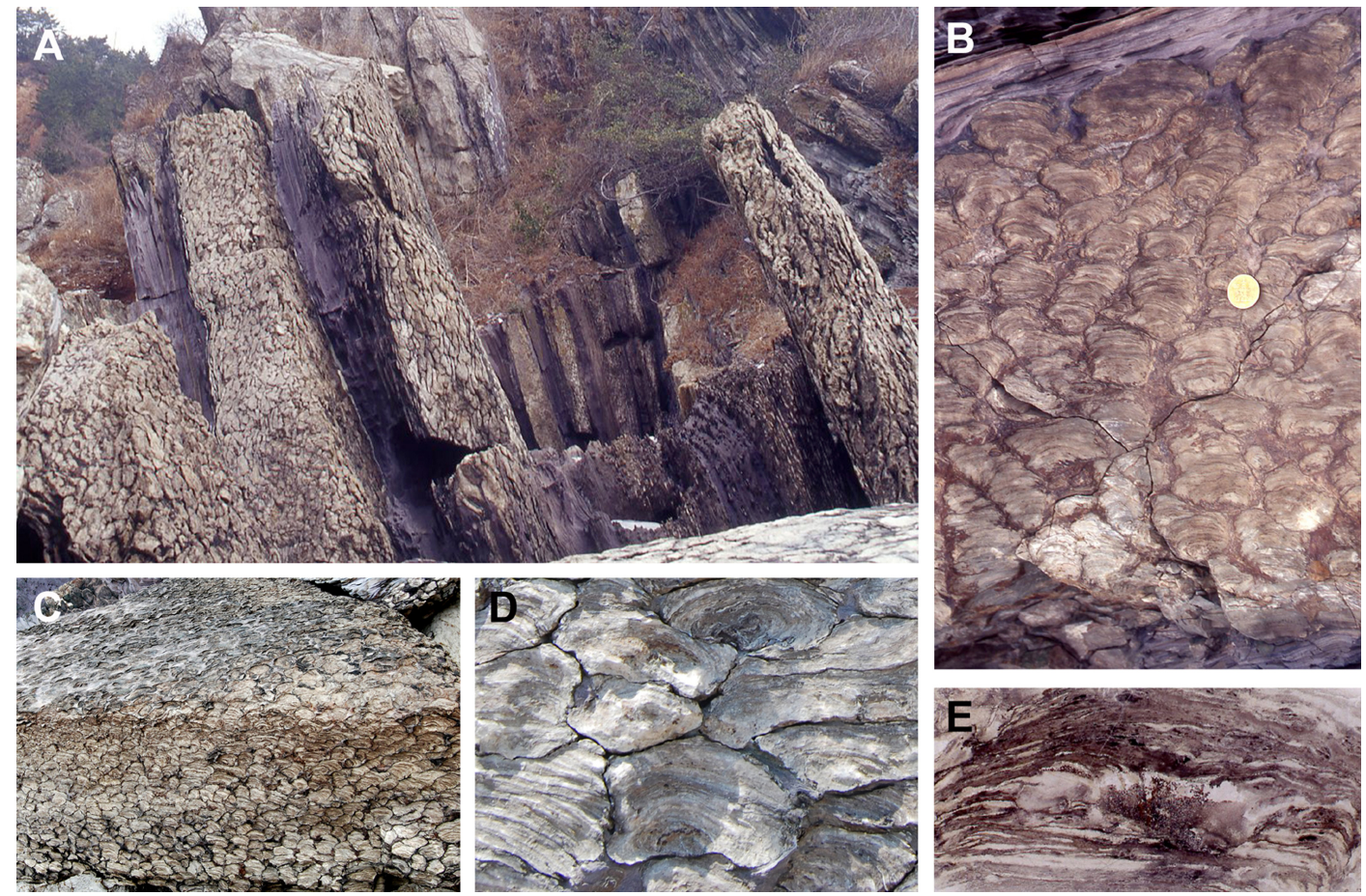

Fig. 3. Stromatolites at Loc. 1 near Nowha village. (a) $10 \mathrm{~cm}$ to 1 meter thick stromatolite beds are intercalated within purple siltstone beds. (b) stromatolite bed composed of both domes and columns. (c) a detached piece of stromatolite bed composed predominantly of domes. (d) a close view of oncolite-like domes of stromatolite. (e) thin section of stromatolite dome showing compacted fine lamination and a dark area in lower center is nucleus of dome.

sediment-rich layers are produced if sedimentation or precipitation rates exceed biological growth rates (Gebelein, 1969, Park, 1976; Golubic, 1991). Consequently, microbial mats or bacterial films formed on sediment-water interfaces become organic-rich layers if they grow as stromatolites. Laminae in Socheong stromatolites were generally accumulated parallel to sediment-water interfaces, often forming convex upward curvature in the columnar stromatolites, and concentric lamination was also produced in the lower part of domal stromatolites (Fig. 3D, E). Laminae, where well preserved, are ca. $500 \mu \mathrm{m}-1 \mathrm{~mm}$ thick, steeply convex in columns, and thickly coating at column margins. Although lateral continuity of fine lamination of Socheong stromatolites is not clearly observed and thus fine lamination could not be used for stromatolite identification, such a directional structure could be used as an indicator of presence of biological activities (e.g., photosynthetic metabolism) in the course of stromatolite growth.

Another directional structure is observed on the upper surface of stromatolite beds, in which short and horizontal axes of columns are oriented in parallel toward a certain direction (Fig. 4). Low relief areas filled with clastic sediments are also arranged in parallel with the elongated columns. Consequently, stromatolite bedding surface is characterized by a directional structure of elongated shape of columns' transverse section. Such directional orientations of columns are well documented in modern stromatolites from hypersaline Hamelin Pool of Shark Bay in Western Australia (Hoffman, 1976) and Highborne Cay in Bahamas (Feldmann and McKenzie, 1998). In Hamelin Pool, the elongated stromatolite columns are standing in a row on sand beaches toward a coastal line. That is, stromatolite columns are oriented seaward for the oncoming waves. Such a directionality is known to have formed by wave action removing 

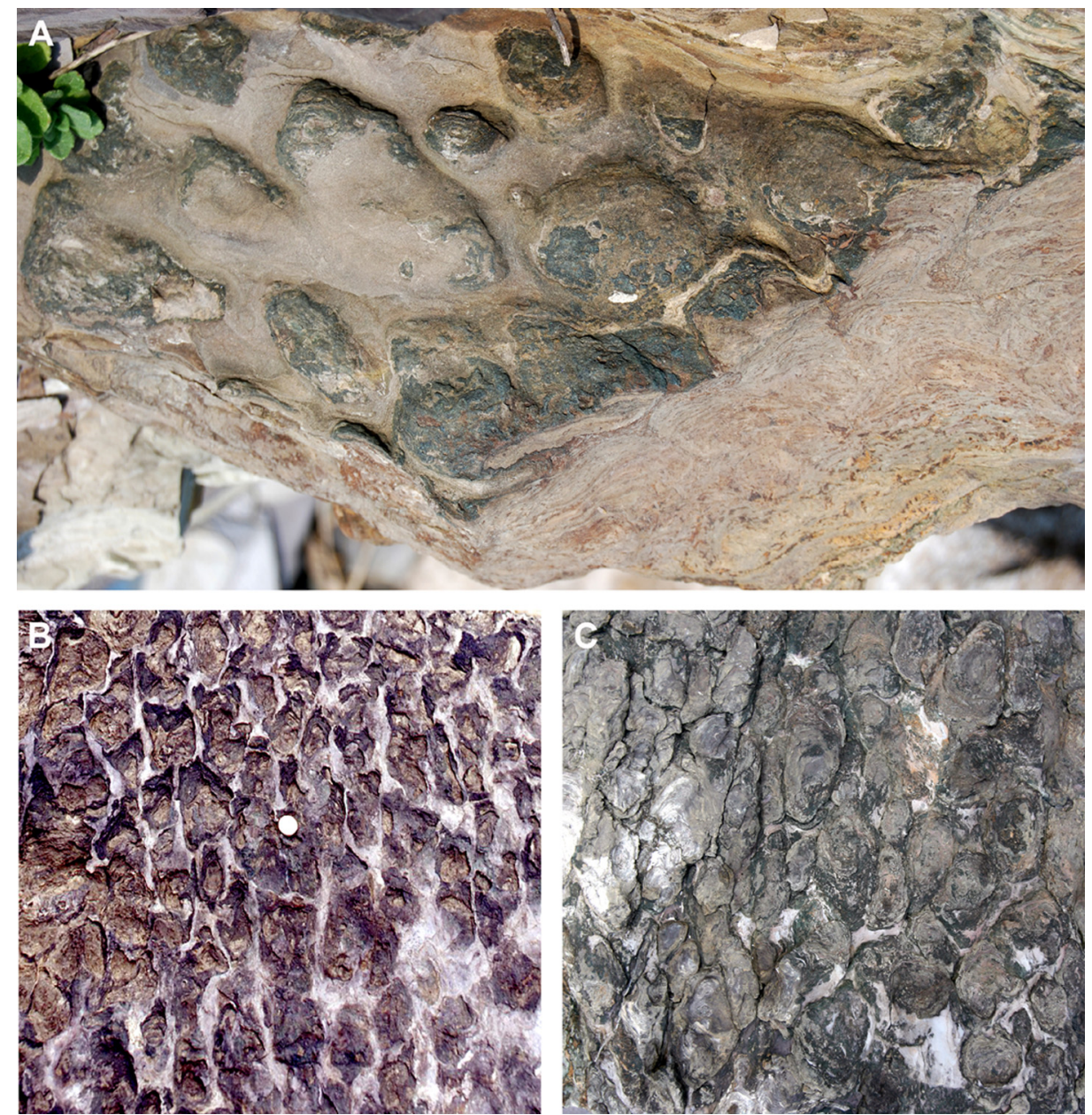

Fig. 4. Surface view of stromatolite beds showing directional structures. (a) horizontally elongated columns are oriented parallel to an ancient coastal line, and fine laminations are visible in cross-section. $(b, c)$ directional structures on the surface of deformed stromatolite beds.

out clastic sediments filled in between stromatolite columns (Golubic, 1991). Restricted occurrence of such directionality only in intertidal stromatolites also support this interpretation because an intertidal zone tends to be affected by strong wave and tide current. Therefore, a directional arrangement of column surfaces of Socheong stromatolites is likely to be attributed to the position of ancient coastal lines when the Socheong stromatolites were formed.

Third type of directionality is well illustrated in vertically erected columns that can be observed in cross section of stromatolite beds. Most of the stromatolite columns and domes in Socheong island also display the vertical orientation to stromatolite bedding surface (Fig. 3B, C). This is a typical and characteristic feature of most Precambrian stromatolites because stromatolite-building microbes were photosynthetic microorganisms that lead columns and/or domes to grow upward toward the sunlight. On the other hand, inclined and non-vertical columns or domes are also observed in some stromatolite beds (Fig. 6). Such inclination was already documented from both modern (Gebelein, 1969; Hofmann, 1973; Awramik and Vanyo, 1986; Chivas et al., 1990) and fossil stromatolites (Nordeng, 1963; Vologdin, 1964; Vanyo and Awramik, 1985; Kusky and Vanyo, 1991; 

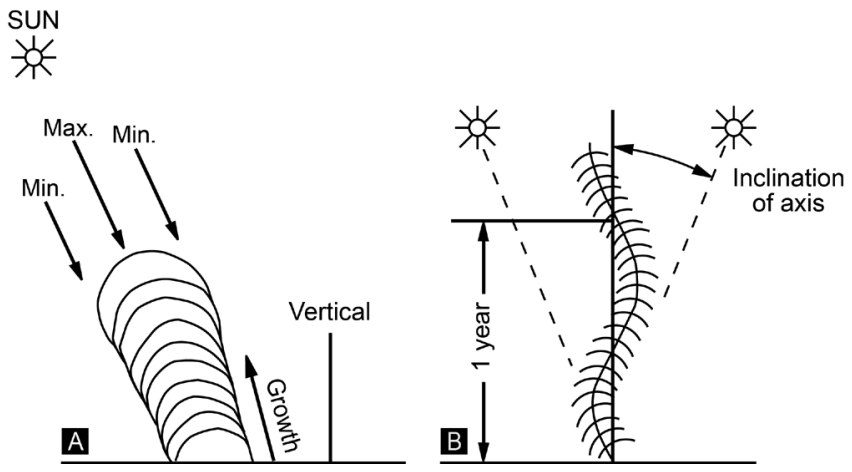

Fig. 5. Schematic diagram explaining (a) inclination of stromatolite columns and (b) sinusoidal growth patterns of columns as a result of heliotropism. Note that maximum light intensity is achieved at the very top of convex upward surface while minimum intensity is reached at margins of columns (modified from Vanyo and Awramik, 1985).
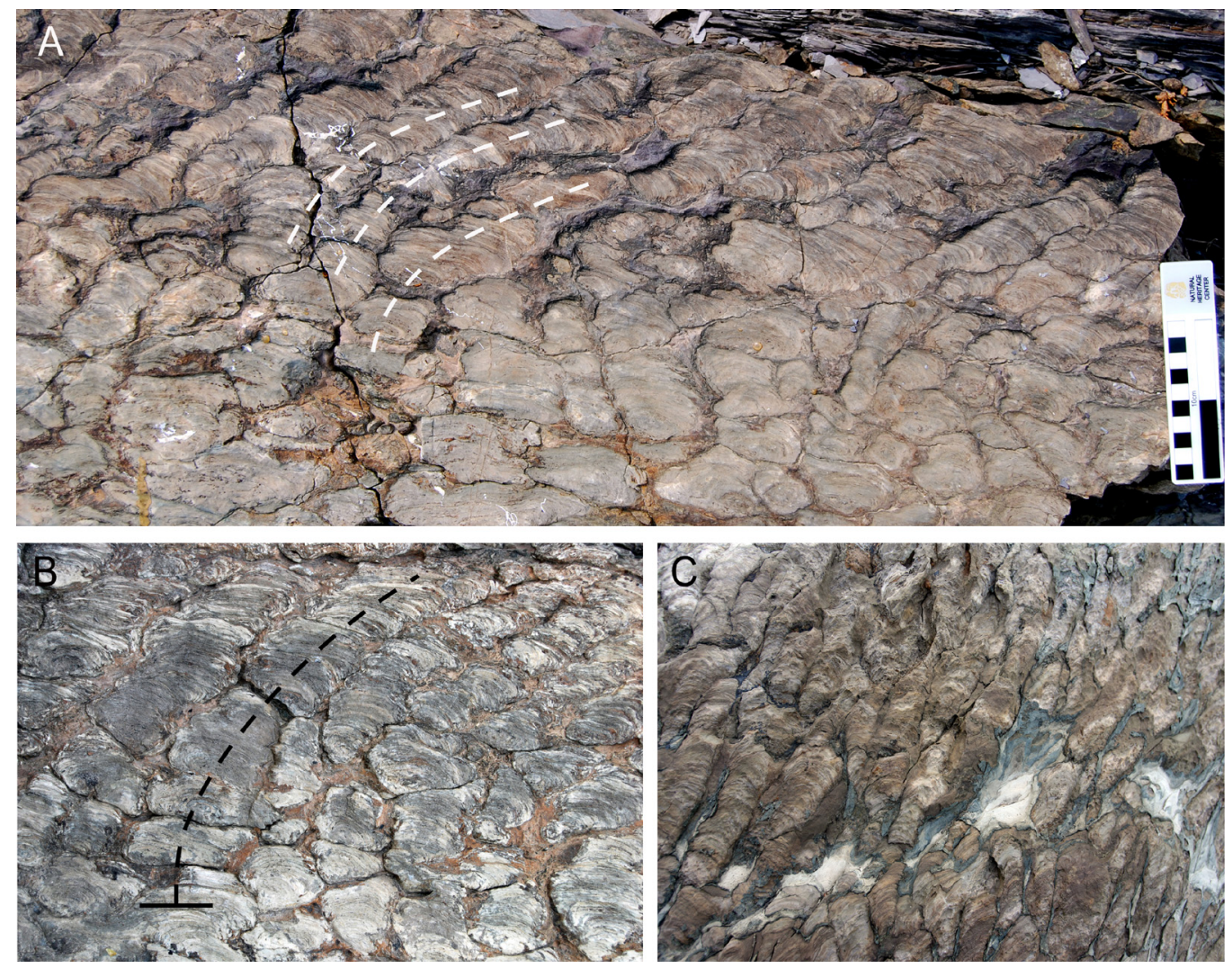

Fig. 6. Inclined columns of Socheong stromatolites. (a) a stromatolite bed composed of both domes and columns. (b) close view of inclined columns, (c) straightly inclined, but not banded columns. Inclined and bended columns (dark and white dashed lines) are clearly recognizable in the upper part of the bed while domes of stromatolites are only dominant in the lower part of the bed.

Williams et al., 2007). Some authors (Nordeng, 1963; Vologdin, 1964; Vanyo and Awramik, 1985; Awramik and Vanyo, 1986) insisted that inclination of columns were due to phototaxis behavior of stromatolite building microbes, a result of heliotropism. Others (Hofmann, 1973; Chivas et al., 1990 ), on the other 
hand, argued that column inclination can also be controlled to a great extent by local environmental conditions.

\section{Discussion on Heliotropism}

Most of stromatolite beds in Socheong island are composed of one or two stromatolite morphotypes: domes and columns. A bed composed only of columnar stromatolites (Fig. 6C) is relatively scarce while most of beds include both columns and domes (Fig. 6A, B). In many cases, however, a clear difference between domes and columns can not be easily recognizable in the field; in general, lower parts of the beds are predominated by oncolite-like domes, and columns become more abundant toward upper surface of the beds (Fig. 6A, B). In stromatolite beds composed of both columns and domes, inclination of column axis relative to net vertical (water-sediment interface) is clearly identifiable particularly in the upper parts of the beds (Fig. 6A, B, black dashed lines). Degree of inclination is rather constant in some stromatolite beds, but more inclined columns toward the top of the bed are also observed in other stromatolite beds. As suggested by many authors (Nordeng, 1963; Vologdin, 1964; Vanyo and Awramik, 1985; Kusky and Vanyo, 1991), such inclination of columns of Socheng stromatolite may represent heliotropism at time of stromatolite formation in ancient Korean sea.

A term "heliotropism" is defined as directional motion of some organisms in response to the direction of sunlight (see more Kudo, 1995; Whippo, 2006). The heliotropism from fossil stromatolites were first recognized in early 1960s by pioneer researchers such as Vologdin (1961, 1963) and Nordeng (1963) who presented evidence of heliotropism in Precambrian branching columnar stromatolite. They postulated that columnar stromatolites show maximum growth when intensity of sunlight is maximized, and thus columns should be inclined in the direction of sunlight (Fig. 5). They even suggested that past position of the Earth's pole and paleolatitudes could be determined by study of directionality of stromatolites.

More detailed and intensive works on heliotropism had been carried out using modern (Awramik and Vanyo, 1986) and fossil stromatolites (Vanyo and Awramik, 1982, 1985). Vanyo and Awramik (1985) documented sinusoidal growth model of stromatolite columns from a columnar stromatolite (e.g., Fig. 5), Anabaria juvensis (identified by Cloud and Semikhatov in 1969), collected by Preston Cloud in 1965 from the Bitter Springs Formation of the Amadeus Basin of central Australia. They argued that both sinusoidal pattern and inclination of columns are a result of heliotropism, non-vertical growth of columns toward incident solar radiation.

Awramik and Vanyo (1986) also found evidence of inclined modern stromatolite tuffs from Shark Bay, Western Australia, and Yellowstone National Park, USA. Their model seems to be reasonable under shallow and low-energy environments where biological factors more strongly control stromatolite morphologies than physical and chemical parameters. According to their model, the most favorable conditions for photosynthetic microbes are achieved at the very top of convex upward column surfaces, while minimum radiative intensity reaches at the bottom of column margins.

Some authors, on the contrary, criticized heliotropism deduced from columns' inclination of stromatolites because other factors also produce column inclination in local environmental conditions (Hofmann, 1973; Gebelein, 1969; Chivas et al., 1990). Particularly Gebelein (1969) found that columns of modern stromatolites tend to incline according to wave and current activity, and Playford et al. (1980) even showed that stromatolites oriented and inclined in the up-current direction toward the sediment supply. Under the conditions characterized by high-energy and high sedimentation rates, local environmental conditions are likely to influence more effectively on column morphology than microbial response to sunlight. Awramik and Vanyo (1986) also noticed this phenomenon, mentioning "Heliotropically oriented stromatolites are not ubiquitous at all sites (p. 1280)". 
Recently, more severe criticism against heliotropism from fossil stromatolites [particularly Vanyo and Awramik (1985)'s work] was raised by Williams et al. (2007). With re-investigation of original samples of Vanyo and Awramik (1985) and field observation of 11 additional samples from the Amadeus Basin, they recognized that stromatolite columns were strongly branching, diverging and converging. They also found no clear sinusoidal growth pattern from stromatolite columns of the Bitter Springs Formation. Based on such observations, they insisted finally that "heliotropism cannot have controlled such various non-vertical growth patterns (p. 87)".

Inclined columns of Socheong stromatolites (Fig. 6) may have formed as a result of either heliotropism (e.g., Vanyo and Awramik, 1985) or under influence of local environmental conditions such as wave and sediment supply (e.g., Gebelein, 1969; Playford et al., 1980). As Awramik and Vanyo (1986) suggested, if Socheong stromatolites would have been deposited under calm and clear water conditions, it seems reasonable to regard inclination of Socheong stromatolites as heliotropism. Under such an environment, stromatolitebuilding photosynthetic filamentous microbes (particularly cyanobacteria) would have oriented to sunlight in order to get maximum intensity of solar energy. If this is the case, we may be able to determine past position of Earth's pole during the period of Socheong stromatolite deposition at ancient Korean sea.

However, general lithology of Socheong island and sedimentary structures are not likely to support theory of heliotropism. Most of sedimentary rocks of Socheong island are mainly composed of larger than silt-sized sediments with diverse sedimentary structures (ripple marks, mud cracks, raindrops, and cross bedding), which indicates not only shallow but also high energy depositional environments. Under these depositional conditions, directional movement of filamentous cyanobacteria toward the incident sunlight could not be reflected in stromatolite columns because sediment supply and wave activity would have played a major role on column morphogenesis (e.g., Gebelein, 1969; Playford et al., 1980).
Heliotropism from Socheong stromatolites could also be rejected by observations that no sinusoidal growth patterns are identified from the stromatolite columns, and that column inclination does not show constant angles throughout the stromatolite beds (Fig. $6 \mathrm{~A}, \mathrm{~B})$. In addition, angles of column inclination change within the same stromatolite bed; no clear inclination of columns is detected at lower level, but angles of inclination tend to increase toward upper level of stromatolite beds. If the inclination was due to heliotropism, it should show a constant angle bending from bottom to top of the beds.

As mentioned earlier, sedimentary sequences of Socheong island were more or less highly metamorphosed due to intrusion of igneous rocks; intrusive igneous bodies are easily observed from the island (Fig. 1, Fig. 2A). The intrusion must have deformed severely structures of sedimentary rocks. Micro to macro scale folds found in sedimentary rocks (Fig. 2B, C) and compacted stromatolite beds (Fig. 2D, E) are indicative of structural deformation. Therefore, the inclination of Socheong stromatolites could be better interpreted as a secondary structural deformation probably after formation of stromatolite columns, rather than as a result of heliotropism.

However, in this paper, we do not clearly reject heliotropism interpretation for inclined columns of Socheong stromatolites. This is because the original position of stromatolite columns were also lost if structural deformation would have affected throughout the whole sedimentary rocks of Socheong island. Systematic approach for stromatolite morphogenesis, paleomagnetic analyses for determination of past pole, and study on structural deformation should be, therefore, necessary in order to test the validity of heliotropism from Socheong island.

\section{Summary}

Heliotropism refers to positive movement of an organism toward the direction of specular sunlight. Such a positive movement of organisms often produces interesting directional structures in sedimentary rocks, 
particularly in stromatolite. Therefore, fossil stromatolites (particularly Precambrian columnar stromatolites) were suggested as a possible indicator of heliotropism. Some authors even argued that position of Earth's past poles and paleolatitudes could be determined from the Precambrian stromatolites. Criticisms were also raised by some researchers, noting that other factors including wave action and sediment supply often create inclined columns of stromatolites.

It is unclear whether inclined columns of Socheong stromatolites were due to heliotropism or influence of local environmental conditions such as wave and sediment supply. If we take considerations as follows, 1) general lithology and sedimentary structures of Socheong island, 2) observation that angles of columns' inclination are not consistent throughout the stromatolite beds, and that vertical columns are also found in stromatolite beds, 3) igneous intrusion that would have caused structural deformation of sedimentary rocks of Socheong island, the inclination of Socheong stromatolites could be better interpreted as a secondary structural deformation probably after formation of stromatolite columns, rather than as a result of heliotropism.

\section{Acknowledgments}

This research was financially supported by the National Research Institute of Cultural Heritage (NRICH-1305-A21F). Valuable comments from an anonymous reviewer and Dr. Dong-Chan Lee have improved the quality of this paper.

\section{References}

Awramik, S.M. and Vanyo, J.P., 1986, Heliotropism in modern stromatolites. Science, 231, 1279-1281.

Chivas, C.R., Torgersen, T., and Polach, H.A., 1990, Growth rates and Holocene development of stromatolites from Shark Bay, Western Australia. Australian Journal of Earth Sciences, 37, 113-121.

Cloud, P.E. and Semikhatov, M.A., 1969, Proterozoic stromatolite zonation. American Journal of Science, 267, 1017-1061

Feldmann, M. and McKenzie, J.A., 1998, Stromatolite- thrombolite associations in a modern environment, Lee Stocking Island, Bahamas, Palaios, 13, 201-212.

Gebelein, C.D., 1969, Distribution, Morphology and accretion rate of Recent subtidal algal stromatolites, Bermuda. Journal of Sedimentary Petrology, 39, 49-69.

Golovenok, V.K., 1989, Precambrian microfossils in cherts and their biostratigraphic significance. Soviet Geology, 8, 41-48.

Golovenok, V.K., Belova, M.Yu., and Kurbatskaya, F.A., 1989, The first Obruchevella find in the Vendian deposits of the central Urals, Doklady Akademii Nauk, 309, 701-705.

Golovenok, V.K. and Belova, M.Yu., 1994, "Gigantism" in Precambrian microfossils and its biostratigraphic significance. Stratigraphy and Geological Correlation, 6, 514-519.

Golubic, S., 1976, Organisms that build stromatolites. In: Walter, M.R. (ed.), Stromatolites. Elsevier, Amsterdam, 113-148.

Golubic, S., 1991, Modern stromatolite-a review. In: Riding, R. (ed), Calcareous Algae and Stromatolites, Springer-Verlag, Berlin, 541-561.

Golubic, S. and Focke, J.W., 1978, Phormidium hendersonii Howe: identity and significan of a modern stromatolite building mocroorganism. Journal of Sedimentary Petrology, 48, 751-764.

Golubic, S., Seong-Joo, L., and Browne, K., 2000, Cyanobacteria: architects of sedimentary structures. In Riding, R and Awramik, A. (eds.), Microbial Sediments. Springer-Verlag, Berlin, 57-67.

Hofmann, H.J., 1969, Attributes of stromatolites. Geological Survey of Canada Paper, 39, 58-69.

Hofmann, H.J., 1973, Stromatolites: Characteristics and utility. Earth Science Reviews, 9, 339-373.

Hofmann, H.J., 1976, Stromatoid morphometrics. In: Walter, M.R. (ed.), Stromatolites. Elsevier, Amsterdam, 45-54.

Hoffman, P., 1976, Stromatolite morphogenesis in Shark Bay, Western Australia. In: Walter, M.R. (ed.), Stromatolites. Elsevier, Amsterdam, 261-271.

Kim, J.Y. and Kim, T. S., 1999, Occurrence of geological significance of stromatolites from the Precambrian strata in the Socheong Island, Incheon, Korea. Journal of Korean Earth Science Society, 20, 111-125.

Kim, J.Y., Kim, K.S., and Kim T.S., 1999, Raindrop imprints from the late Proterozoic Sangwon System of the Sochong Island of Ongjin-gun, Incheon, Korea. Journal of the Korean Earth Science Society, 20, 55-60.

Kim, J.Y. and Han, S.H., 2010, Geology and Stromatolite Fossil Localities of Socheong Island, Korea: An Introductory Review. Journal of Korean Earth Science Society, 31, 8-17. (in Korean)

Knoll. A.H. and Golubic, S., 1992, Modern and ancient 
cyanobacteria. In: Schidlowski, M., Golubic, S., Kimberley, M.M., McKirdy, D.M. and Trundinger, P.A. (eds.), Early Organic Evolution: Implications for Mineral and Energy Resources. Springer, Berlin, 450462.

Komar, V.A., 1964, Columnar stromatolites from the Riphean of the North Siberian Platform. Paleontologiya I Biostratigrafiya Vypusk, 6, 84-105. (in Russian)

Kong, D.Y., 2010, Korean stromatolites from the Precambrian, Paleozoic, and Mesozoidc sedimentary sequences: distribution, morphotypes and genesis. Ph.D. thesis, Kyungpook National University, Daegu, Korea, $235 \mathrm{p}$.

Krylov, I.N., 1976, Approaches to the classification of stromatolites. In: Walter, M.R. (ed.), Stromatolites, Elsevier, Amsterdam, 31-43.

Kudo, G., 1995, Ecoligical significance of flower heliotropism in the spring ephemeral Adonis romosa (Ranunculaceae). Oikos, 72, 14-20.

Kusky T.M. and Vanyo J.P., 1991, Plate reconstruction using stromatolite heliotropism: principles and applications. Journal of Geology, 99, 321-335.

Lee, S.-J., Kim, J.Y., and Lee, K.C., 2003, Bacterial microfossils from Precambrian sedimentary rocks, Socheong Island, Korea. Journal of the Geological Society of Korea, 39, 171-182. (in Korean)

Mankiewicz, C., 1992, Obruchevella and other microfossils in the Burgess Shale: preservation, and affinity. Journal of Paleontology, 66, Neues Jahrbuch fr Geologie und Palontologie Abhandlung, 119, 93-102.

Nordeng, S.C., 1963, Precambrian stromatolites as indicators of polar shift. In: Munyan, A.C. (ed.), Polar Wondering and Continental Drift. Society of Economy, Paleontology and Mineralogy, Special Publication 10, 131-139.

Paik, R.J., Ri, S.R., Kim, S.J., and Im, M.G., 1996, A geological map of Korea $(1: 1,000,000)$. The Institute of Geology, State Academy of Science, DPR of Korea. $115 \mathrm{p}$.

Pak, M.H., 1986, On stromatolite fossil found in the Sangwon System of the Sangwon-Yonsan Region. Geology and Geography, 4, 14-20.

Park, R.K., 1976, A note on the significance of lamination in stromatolites. Sedimentology, 24, 379-393.

Petrov, P.Yu., 1996, Model of stromatolites morphogenesis. Lithology and Mineral Resources, 31, 229-239.

Playford, P.E., 1980, In some cases, oversteepening away from current has been observed. West Australian Geological Survey Annual Report, 73, 201-243.
Schopf, J.W., 1996, Cyanobacteria: pioneers of the early Earth. In: Prasad, A.K.S.K., Neinow, J.A and Rao, V.N. (eds.), Contribution in Phycology. Cramer, Berlin, 1331.

Semikhatov, M.A., Gebelein, G.D., Cloud, P., Awramic, S.M and Benmore, W.C., 1979, Stromatolite morphogenesis-progress and problem. Canadian Journal of Earth Science, 16, 992-1015.

Seong-Joo, L., Browne, K., and Golubic, S., 2000, On stromatolite lamination. In: Riding, R. and Awranik, A (eds.), Microbial Sediments. Springer-Verlag, BerinHeidelberg, 16-24.

Vanyo, J.P. and Awramik, S.M,. 1982, Length of day and obliquity of the ecliptic $850 \mathrm{Ma}$ ago: preliinary results of a stromatolite growth model. Geophysical Research Letters, 9, 1125-1128.

Vanyo, J.P. and Awramik, S.M., 1985, Stromatolites and Earth-Sun-Moon dynamics. Precambrian Research, 29, 121-142.

Vanyo, J.P., Hutchinson, R.A., and Awramik, S.M., 1986, Heliotropism in microbial stromatolite growths at Yellowstone National Park: geophysical inferences. Eos 67, 153 and 155-156.

Vologdin, A.G., 1961, Eye witness of the migration of the poles. Prioroda, 11, 102-103. (in Russian)

Vologdin, A.G., 1963, Stromatolites and phototropism. Doklady of the Academy of Sciences of the USSR 151, 683-686.

Vologdin, A.G., 1964, Stromatolites and heliotropism. Doklady of the Academy of Sciences of the USSR 151, 196-198.

Walter, M.R., Bauld, J., and Brock, T.D., 1976, Microbiology and morphogenesis of columnar stromatolites (Conophyton, Vacerrilla) from hot springs in Yellowstone National park. In: Walter, M.R. (ed.), Stromatolites. Developments in Sedimentology, 20, Elsevier, Amsterdam, 273-310.

Walter, M.R., Grotzinger, J.P., and Schopf, J.W., 1992, Proterozoic stromatolites. In Schopf J.W. and Klein C. (eds.), The Proterozoic Biosphere, A Multidisciplinary Study. Cambridge University Press, New York, 253-260.

Whippo, C.W., 2006, Phototropism: bending toward enlightment. The Plant Cell, 18, 1110-1119.

Williams, G.E., Jenkins, R.J.F., and Walter, M.R., 2007, No heliotropism in Neoproterozoic columnar stromatolite growth, Amadeus Basin, central Australia: Geophysical implications. Palaeogeography, Palaeoclimatology, Palaeoecology, 249, 80-89.

Manuscript received: July 12, 2013

Revised manuscript received: August 9, 2013 Manuscript accepted: August 12, 2013 